\title{
Characteristics of Concrete made with Gravel from Selected Mining Sites in Osun State, South-Western. Nigeria
}

\author{
${ }^{1}$ J.A Ige and ${ }^{2}$ S.O. A jamu \\ ${ }^{1,2}$ Department of Civil Engineering, Ladoke Akintola University of Technology, Ogbomoso \\ Correspondence e-mail: soajamu@lautech.edu.ng
}

\section{ABSTRACT}

Granite is an essential constituent material in concrete production as its inadequate quantity has led to massive application of gravel in construction works. Locally sourced gravels are characterized with impurities which affect the quality of the concrete. Therefore, this study investigated the quality of locally-sourced gravel across Osun State.

Gravel samples were obtained from the borrowed pits across the three Senatorial Districts viz Osun West (OSW); Osun Central (OSC); and Osun East (OSE) of the State. The locations are: OSW [Irewole (IRW: $07^{0} 30^{\prime} \mathrm{N} 04^{0} 20^{\prime} \mathrm{E}$ ), Egbedore (EGBE: $07^{0} 40^{\prime} \mathrm{N} 04^{0} 30^{\prime} \mathrm{E}$ ), Ede North (EDE: $\left.07^{0} 40^{\prime} \mathrm{N} 04^{0} 30^{\prime} \mathrm{E}\right)$ ]; OSC [Ifelodun (IFD: $07^{0} 55^{\prime} \mathrm{N} 04^{0} 41^{\prime} \mathrm{E}$ ), Osogbo (OSO: $7^{0} 46^{\prime} \mathrm{N} 4^{0} 34^{\prime} \mathrm{E}$ ), Olorunda (OLO: $7^{0} 46^{\prime} \mathrm{N} 4^{0} 34^{\prime} \mathrm{E}$ )] ; and OSE [Ilesa West (ILS: $70^{\circ} \mathrm{N} 50^{\circ} \mathrm{E}$ ), Ife Central (IFE: $70^{0} 50^{\prime} \mathrm{N} 4^{0} 69^{\prime} \mathrm{E}$ ), Ife East (IFEE: $\left.70^{0} 50^{\prime} \mathrm{N} 4^{0} 69^{\prime} \mathrm{E}\right)$ ]. Physical examination in accordance with BS 882, Aggregate Crushing Value (ACV) test, and sieve analysis were carried out on the gravel samples. Concrete cubes were cast, subjected to Slump, Compressive strength and compared with BS 812 Standard.

Physical examination shows samples having dry, dark, and brownish gravelly irregular shapes for OSW and OSC while they were predominantly reddish, gravelly irregular shapes for OSE. The ACV results were: IRW: 19.13, EGBE: 20.94, EDE: 21.87 for OSW, IFD: 34.99, OSO: 37.33, OLO: 41.09 for OSC, and ILS: 25.25, IFE: 30.84, IFEE: $44.86 \%$ for OSE. The sieve analysis results of the respective percentage for each sample passing sieve $14 \mathrm{~mm}$ were: OSW [IRW: 72.16, EGBE: 68.44, EDE: 76.41]; OSC [IFD: 75.91, OSO 78.25, OLO: 77.64]; and OSE [ILS: 67.14, IFE: 76.75, IFEE: 80.22]. The average slump test values for the fresh concrete produced were: OSW [IRW: 35.5, EGBE: 34.78, EDE: 34.94]; OSC [IFD: 42.59, OSO: 45.75, OLO: 49.70]; and OSE [ILS: 37.41, IFE: 39.44, IFEE: $54.39 \mathrm{~mm}$ ]. The respective compressive strength test results (in N/mm ${ }^{2}$ ) for 28 days concrete were: OSW [IRW: 19.76, EGBE: 18.26, EDE: 17.23]; OSC [IFD: 12.90, OSO: 10.21, OLO: 9.58]; and OSE [ILS: 16.43, IFE: 14.50, IFEE: 6.44].

The study revealed that the gravel materials from Osun West Senatorial District possessed the desirable strength and characteristics as compared to the Standard. The gravel can be used in place of granite for construction works.

Key words: Concrete and gravel,

\subsection{INTRODUCTION}

Construction activities in Osun State depend largely on the naturally occurring aggregate (gravel and sand) that are generally available in the State. Aggregate constitutes a prominent material in construction, especially in concrete works. 
The naturally occurring gravel aggregates has over time being used for structural concrete construction as an economical substitute to granite, believing that using granite alone or the mixture of the two coarse aggregates (granite and gravel) in a designed proportion can give the required strength and durability.

Gravel and sand are principal construction materials worldwide. Sand and gravel represent loose sediments that originated from transport and deposition of more or less weathered rock fragments for certain size (gravel: $2-128 \mathrm{~mm}$, sand: $0.063-2 \mathrm{~mm}$ ) which are products of the weathering of rocks. They mostly consist of pebbles and boulders of resistant rocks and minerals (quartz, feldspar, quartzite, granite, and so on) to a smaller extent of less resistant rocks and minerals (mostly of crystalline or metamorphic and sedimentary rocks). Sand and gravel also contain silt and clayed fraction. Major impurities are humus, clay intercalation, higher content of floatable particles and sulphur, high content of unsuitable (shape wise) or weathered grains. Gravel and sand deposits are common all over the world and they are not recognized (Colombia Encycopedia, 2013).

Concreting which is a major process prominently used in building and civil engineering works, comprises of a mixture of material (fine aggregate (sand), coarse aggregate (gravel or granite, cement, and water), in the specified proportions so as to meet some certain requirements in order to predict its efficiency for use that is good workability, required strength and so on. Aggregates which is a prominent material, (usually hard) constitute over $75 \%$ of the total concrete mass thus, aggregate play crucial role in concrete volume and strength (Oni, 2008).

Aggregate type (gravel) and aggregate quantity influence the properties of concrete, its mix and also its economy. However, the mix proportion of aggregate greatly affects the structural performance and the durability characteristic of concrete (Shetty et al 2005). The mix design of coarse aggregate using locally sourced gravel as coarse aggregate instead of granite as become very important in order to achieve acceptable concrete characteristics and the minimum characteristics required for general concrete construction purpose. Concrete mixes are the proportion in which concrete components: cement, fine aggregate, water and coarse aggregate (gravel and granite) are mixed and may be designed either in term of volume or in terms of weight (Adeomi, et al., 2007). Mix design play a major role in determining the characteristic strength of concrete and therefore trial mix designs prior to the concrete construction are necessary and are usually determined.

Aggregates that contribute immensely to concrete efficiency must be sufficiently strong, free from constituents which can react with the cement, be well graded and have very small or no moisture movement. However, since aggregates are the major constituent material by volume, its properties are of great importance in assessing the strength of concrete .

Lack of adequate and insufficient quarry granite production as well as the nature of some gravel with high clay and silt content and need to meet housing and other infrastructural deficit in Osun State with the little state revenue influence the necessity to study the local gravel quality and its availability across the State.

The economic condition makes gravel more attractive for concrete work. Therefore there is need to carry out further engineering evaluation on gravel, especially on how it can be used only as coarse aggregate both for reinforced and mass concrete in construction works, and still establish its concrete strength and made recommendation on what can be done to take care of the fines which are naturally part of gravel for the production of concrete of required strength, workability and durability. 


\subsection{MATERIALS AND METHODS}

\subsection{Description of the study area}

Osun State is an inland State in South-Western Nigeria. Its capital is Osogbo, and it is bounded in the north by Kwara State, in the east partly by Ekiti and Ondo States, in the South by Ogun State and in the West by Oyo State. Total area of Osun State is $9.251 \mathrm{~km}^{2}$ with an estimated population of 4,137,627 people according to 2006 Population Estimate. Osun State falls within the South-Western part of the crystalline basement complex as contained in the geological study of the Western Part of Nigeria by (Azer and Febel, 1963). The gneissic fabric of the country rock is prepared in the undulated lithology. The two principal rock types are quartzite and auger gnesis which are geologically the oldest type in the country.

Figure 1 shows the geographical map of Osun State while Figure 2 shows the 9 selected Local Government areas for the study

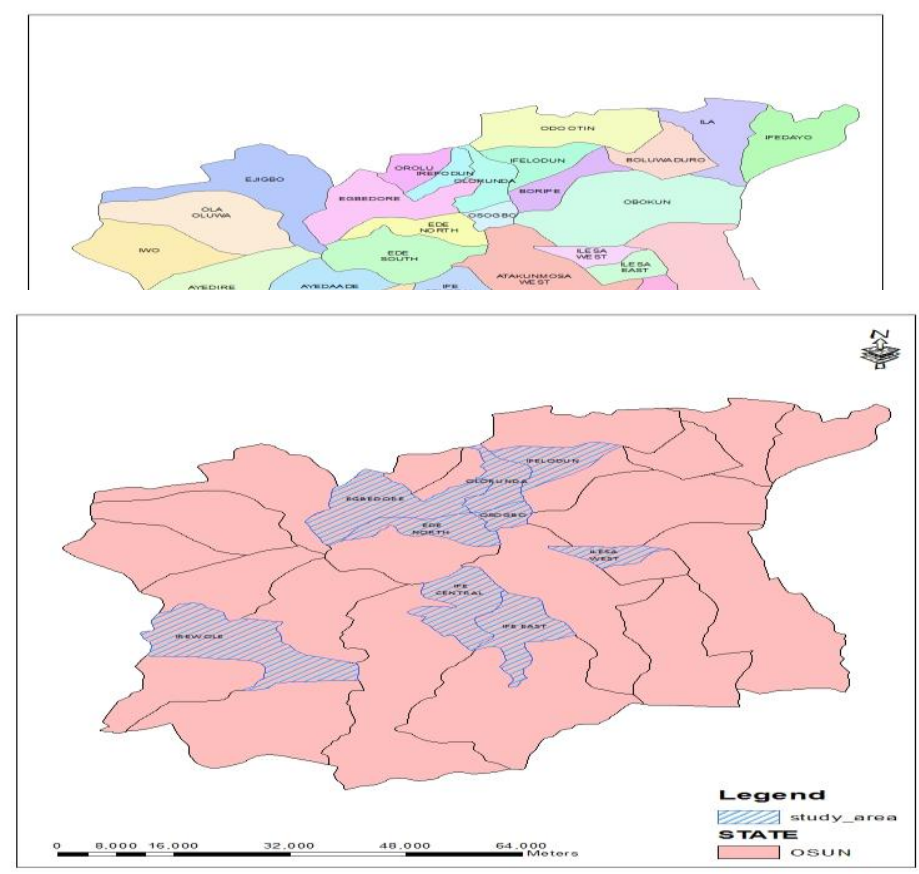

Figure 2 Shows the 9 selected Local Government areas for the study

\subsection{Collection of Sample Materials}

Nine gravel samples were collected from the identified gravel mining site of the selected Local Governments across the State. The fine aggregate was sourced from natural river sand. The cement used for the research was the elephant brand of Ordinary Portland Cement as it was purchased from the local market. The water used was portable water that was free from impurities and chemicals.

\subsection{Tests on Gravel}

Gravel sample were collected from the selected Local Government Areas and the following test result were carried out.

\subsubsection{Sieve analysis}

Sieve analysis was done on the gravel samples. The samples were washed and oven dried for a day ( 24 hours) before being sieve to remove the clay and silt content of the gravel samples through sieve of $0.75 \mathrm{~mm}$ diameter. Proper sieve analysis was later carried out on these samples using a set of sieve with diameter ranging from $5 \mathrm{~mm}, 10 \mathrm{~mm}, 14 \mathrm{~mm}, 20 \mathrm{~mm}$ to $37.5 \mathrm{~mm}$ according 
to BS 882: and BS 1377 part 7 (c) to determine the weight retained (g), cumulative percentage retained, total cumulative percentage passing.

The sieves were arranged with $37.5 \mathrm{~mm}$ sieve at the top and sieve $5 \mathrm{~mm}$ at the bottom. The gravel samples were poured in the set of sieves and shaken vigorously for 5minutes. The particles passing sieves $37.5 \mathrm{~mm}$ was retained on sieves $20 \mathrm{~mm}, 14 \mathrm{~mm}, 10 \mathrm{~mm}$, and $5 \mathrm{~mm}$ sieves respectively.

\subsubsection{Aggregate crushing value (ACV)}

The cylinder of the test apparatus was placed in position on the base plate and the test specimen was added in three layers of approximately equal depth, each layer being subjected to 25 strokes from the tamping rod distributed evenly over the surface of the layer and dropping from a height approximately $50 \mathrm{~mm}$ above the surface of the aggregates. The surface of the aggregate was levelled carefully and inserted the plunger so that it rested horizontally on this surface. Care was taken to ensure that the plunger does not jam in the cylinder. The apparatus with the test specimen prepared was placed in and plunger in position between the platens of the testing machine and loaded it at uniform rate as possible to until the required force of $400 \mathrm{kN}$ was reached in $10 \mathrm{~mm} \pm$ 30s. the load was releases and the crushed material was removed by holding the cylinder over a clean tray of know mass and hammering on the outside of the cylinder with the rubber mallet until the particles were sufficiently distributed to enable the ass of the specimen to fall freely on to the tray. Particles adhering were transferred to the inside of the cylinder, to the base plate and the underside of the plunger, to the tray by means of a stiff bristle brush. The tray and the aggregate were weighed to determine the mass of aggregate used $\left(\mathrm{M}_{1}\right)$ to the nearest gram. Whole of the test specimen was sieved on the tray on the $2.36 \mathrm{~mm}$ test sieve until no further significant amount passed during a further period of $1 \mathrm{~min}$. massed of the fractions passing and retained were weighed and recorded on the sieve to the nearest gram ( $\mathrm{M}_{2}$ and $\mathrm{M}_{3}$ respectively). (BS 812-110:1990) Aggregate crushing value (ACV) test can be calculated according to BS 812-110:1990 thus:

$$
\mathrm{ACV}=\frac{(\mathrm{M} 2)}{\mathrm{M} 1} \times 100 \%
$$

where

$\mathrm{M}_{1}$ is the mass of the test specimen (in $\mathrm{g}$ );

$\mathrm{M}_{2}$ is the mass of the materials passing the $2.36 \mathrm{~mm}$ test sieve (in $\mathrm{g}$ ).

\subsection{Concrete Production}

Mixing-The mixing of materials was done in a concrete platform. A weighted coarse \& fine aggregate was first thoroughly mixed dry. Weighted cement was added to the mixture with shovel, until a uniform distribution of particles is achieved. Clean water of 0.5. Ratio was added and mixed until uniform distribution of aggregate in the paste and workable mix was achieved. External materials were prevented from falling into the mixture during the mixing process. The mixing of materials was done for $20 \mathrm{~m}^{3}$ of concrete at a time.

Casting of concrete-Casting of concrete involves placing of the fresh concrete into the mould; the dimensions of the mould used were $150 \mathrm{mmx} 150 \mathrm{mmx} 150 \mathrm{~mm}$. The moulds were first lubricated with engine oil to enhance easy stripping of the mould. Casting was done in three layers per cube, with each layer compacted 25 blows with the aid of taping-rod. The top layer was smoothened with hand trowel and was kept for 1hour before labelling. The cube is left in the mould for 24 hours before it was removed.

\section{Workability test on Fresh Concrete}

The workability test that was carried out on the fresh concrete was the slump test based on BS1881: part 103(1983).

Slump Test: The slump test was performed using a standard slump cone mould. The mould for the slump test was a frustum of a cone, $300 \mathrm{~mm}$ high. It was placed on a smooth surface with the 
smaller opening at the top, and filled with concrete in three layers. Each layer was temped 25 times with a standard $16 \mathrm{~mm}$ diameter steel rod, rounded at the end, and the top surface was struck off by means of a sawing and rolling motion of the tampering rod. The mould was firmly held against its base during the entire operation: this was facilitated by handles or foot rest brazed to the mould. The reduction or decrease in height of the slump concrete is called slump and was measured to the nearest $5 \mathrm{~mm}$.

\section{Curing of concrete cubes}

The Curing of concrete cubes, which is an exercise to complete the hydration of cement in the hardened concrete, began 24 hours after casting. The cubes were removed and placed in a water storage tank, for continue curing of the concrete cubes. And for each of the concrete cubes curing period of 3 days, 7 days, 14 days, 21 days, and 28 days was adopted, and after the respective ages three concrete cubes were removed from the water and tested for comprehensive strength respectively.

\section{Density determination test}

BS 1881 gives the best conduct of cubes test and to determine the density of concrete cubes the following apparatus was used. The weighing balance, weight of different value of $5 \mathrm{~kg}$, $2 \mathrm{~kg}, 0.5 \mathrm{~kg} 0.2 \mathrm{~kg}$.

Each concrete cube was removed from the water and allowed to dry for 5 minutes. The cube was placed on the weighing balance to determine its weight. The reading on the gauge taken and recorded and this was repeated for all the cubes and the results were subsequently recorded.

The density of each cube is calculated thus:

$$
\text { Density of concrete }=\frac{\text { weight of cube } \mathrm{kg}}{\text { volume of mould }(\mathrm{m} 3)}
$$

\section{Compressive Strength Test}

This test was carried out on hardened concrete cubes as objective of the test was to determine the compressive strength produced by concrete made with different gravel obtained from the selected mining site across the State. The apparatus for this test is the hydraulic operated crushing machine.

After curing for specific ages of $3,7,14,21$, and 28 days, three cubes per sample were removed from the curing tank and was centrally placed in the crushing machine. Crushing load was gradually applied on the crushing machine, until no further movement of gauge pointer was observed showing that the concrete cube has "crack" i.e. failed. At this point the reading on the gauge was taken and recorded as the crushing load at failure. The crushing load obtained from the machine was divided by the load bearing area of concrete cubes which resulted to the comprehensive strength in $\mathrm{N} / \mathrm{mm}^{2}$ in accordance to BS 1881: part 118, 1983.

The comprehensive strength of concrete is calculated thus:

$$
\text { Comprehensive strength }\left(\mathrm{N} / \mathrm{mm}^{2}\right)=\frac{\text { crushing }}{\text { Cross Section area of Cube }}
$$

\subsection{RESULTS AND DISCUSSION}

\subsection{The Physical properties of the gravel}

Table 1 shows the physical properties of the gravel samples collected from the various selected Local Government. The description of the gravel sample collected from Irewole, Egbedore, Ede North ,Osogbo and Olorunda Local Government shows dry, dark brownish gravelly with irregular shapes while the sample from Ilesa West, Ife Centre, Ifelodun, Ife East Local Government could be described as dry reddish brown, gravelly with irregular shapes. 
Table 1 Physical Properties of the Gravel Sample Collected from Mining Sites

\begin{tabular}{lll}
\hline S/N & Local Government Area & Descriptions \\
\hline 1 & Irewole & Dry, dark, brownish gravelly irregular shape. \\
2 & Egbedore & Dry, dark, brownish gravelly irregular shape. \\
3 & Ede North & Dry, dark brownish gravelly irregular shape. \\
4 & Ilesa West & Dry, dark reddish gravelly irregular shape. \\
5 & Ife Centre & Dry, dark reddish gravelly irregular shape. \\
6 & Ifelodun & Dry, dark reddish gravelly irregular shape. \\
7 & Osogbo & Dry, dark brownish gravelly irregular shape. \\
8 & Olorunda & Dry, dark brownish gravelly irregular shape. \\
9 & Ife East & Dry, dark reddish gravelly irregular shape.
\end{tabular}

\subsection{Particle size Distribution}

The range of coarse aggregate used for this study is between $14.76 \mathrm{~mm}$ and $19.05 \mathrm{~mm}$ diameter size and this was strictly adhered to.

The range of coarse aggregate adopted for the study fell on sieve size $(20 \mathrm{~mm}, 14 \mathrm{~mm}$, and $10 \mathrm{~mm})$ respectively which was described as well graded medium gravel on the particle size distribution chart

\subsection{Slump Test}

The result of the slump test conducted on the concrete mix ratios of 1:2:4. Shown that the average slump test values ranges from 34.54-54.39, the lowest value was recorded at Irewole LGA followed by Egbedore, Ede North, Ilesha West, Ife Central, Ifelodun, Osogbo, Olorunda, and Ife East which has the highest value of 54.59. The entire slump test for the trial mixes were true test (bellow 50), except Ife East slump test that shear (above 50). Figure 3 shows the column chart for the concrete slump test for all the selected Local Governments.

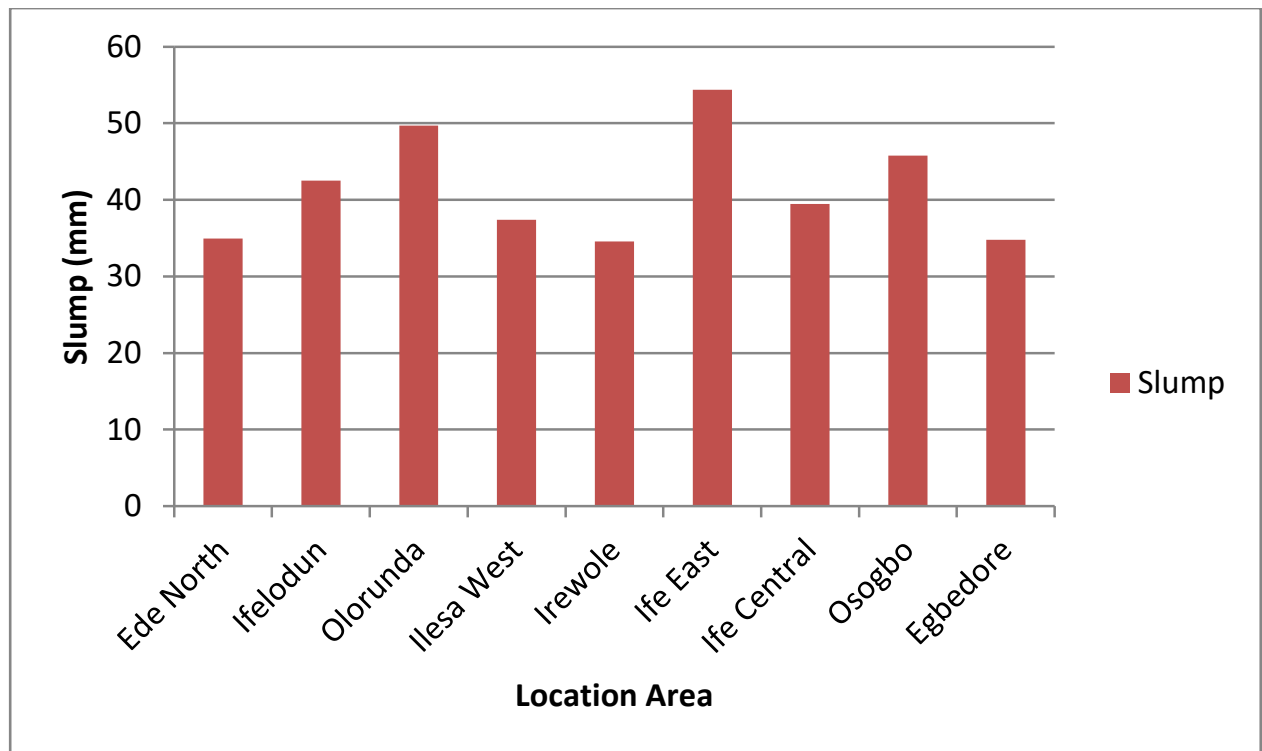

Figure 3 Column chart for the concrete slump test for all the selected Local Governments. 


\subsection{Concrete Density Result}

Figure 4 shows the results obtained from density determination for concrete cubes at $3^{\text {rd }}, 7^{\text {th }}, 14^{\text {th }}$, and $28^{\text {th }}$ days respectively;

Irewole Local Government: The density result for concrete produced with gravel from the local government increases as the average density increases from $2620 \mathrm{~kg} / \mathrm{m}^{3}$ at age 3 days to $2622 \mathrm{~kg} / \mathrm{m}^{3}$ at age 28 days.

Egbedore Local Government: The result for Egbedore gravel sample also indicate an increment in the concrete density as the average density increases from $2614 \mathrm{~kg} / \mathrm{m}^{3}$ at age 3 days to 2680 $\mathrm{kg} / \mathrm{m}^{3}$ at age 28 days.

Ede North Local Government: The average concrete density of the gravel sample increases from $2572 \mathrm{~kg} / \mathrm{m}^{3}$ at age 3 days to $2634 \mathrm{~kg} / \mathrm{m}^{3}$ at age 28 days.

Ilesa West Local Government: The average density increases from $2572 \mathrm{~kg} / \mathrm{m}^{3}$ at age 3 days to $2645 \mathrm{~kg} / \mathrm{m}^{3}$ at age 28 days.

Ife Centre Local Government : The average density indicate that concrete at age 28 days exhibit maximum density of $2660 \mathrm{~kg} / \mathrm{m}^{3}$ and with minimum density at age 3 days of $2621 \mathrm{~kg} / \mathrm{m}^{3}$.

Ifelodun Local Government: The density result for concrete made with gravel sample from the local government and with an average density increment from $2477 \mathrm{~kg} / \mathrm{m}^{3}$ at age 3 days to 2534 $\mathrm{kg} / \mathrm{m}^{3}$ at age 28 days.

Osogbo Local Government: The values of average density indicate increment in the results as the average density increases from $2282 \mathrm{~kg} / \mathrm{m}^{3}$ at age 3 days to $2424 \mathrm{~kg} / \mathrm{m}^{3}$ at age 28 days.

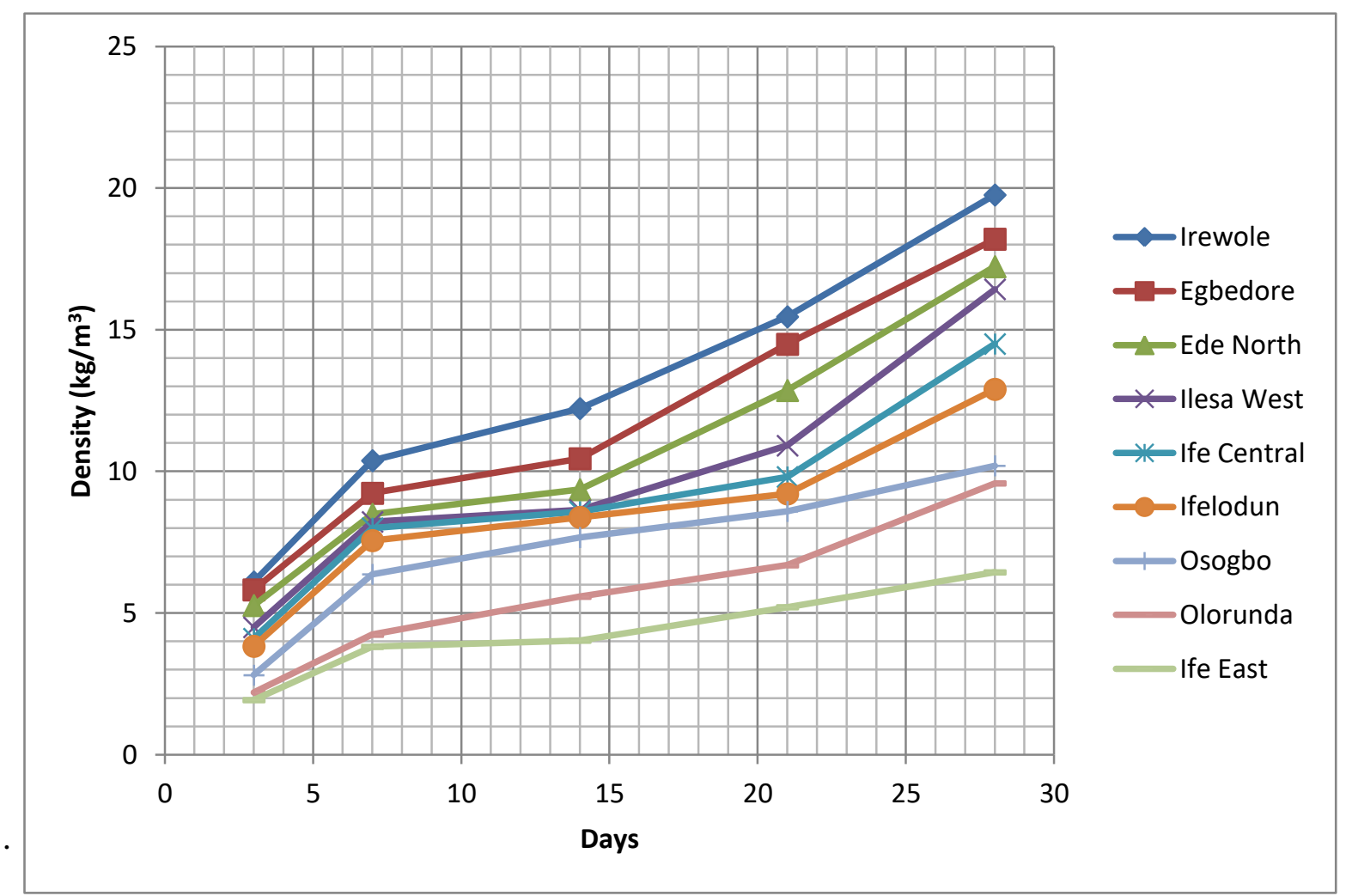

Figure 4 Summary of Density for all Gravel Samples in the Selected Local Governments

Olorunda Local Government: The result observed shows that, the average density of the cubes from the local government increase from $2104 \mathrm{~kg} / \mathrm{m}^{3}$ at age 3 days to $2359 \mathrm{~kg} / \mathrm{m}^{3}$ at age 28 days Ife East Local Government: the result shows an increase in density values of the cubes from $2016 \mathrm{~kg} / \mathrm{m}^{3}$ at age 3 days to $2306 \mathrm{~kg} / \mathrm{m}^{3}$ at age 28 days. 
It can be generally stated that the average concrete density increases from age 3 days to age 28 days respectively for the concrete cubes cast for all the gravel samples collected from the selected Local Governments.

\subsection{Compressive strength test.}

The result obtained from Crushing of Concrete Cubes casted with the gravel samples collected from all the nine (9) local governments were shown in Figure 5 The summary of comprehensive strength $\mathrm{N} / \mathrm{mm}^{2}$ against the curing days of all the gravel samples in the Selected Local Governments. From the results, for all the nine Local Governments selected, it is generally observed that, the compressive strength increases as the day's increases.

However, concrete cubes produced with gravel samples obtained from Irewole Local Government exhibited the highest average compressive strength of $10.39 \mathrm{~N} / \mathrm{mm}^{2}$ and $16.59 \mathrm{~N} / \mathrm{mm}^{2}$ at 7 days and 28 days compared to Ife east local government with lowest compressive strength of $1.93 \mathrm{~N} / \mathrm{mm}^{2}$ and $6.44 \mathrm{~N} / \mathrm{mm}^{2}$ at 7 days and 28 days respectively.

Also, it is evident that concrete made with gravel sample from Irewole Local Government has the maximum strength followed by Egbedore Local Government and Ede North Local Government as shown in the following order,

Irewole Local Government compressive strength > Egbedore Local Government compressive strength > Ede North Local Government compressive strength > Ilesa West Local Government compressive strength > Ife Centre Local Government compressive strength > Ifelodun Local Government compressive strength > Osogbo Local Government compressive strength > Olorunda Local Government compressive strength > Ife East Local Government compressive strength as this shows from the plot of compressive strength and the curing age in days for all the selected Local Governments.

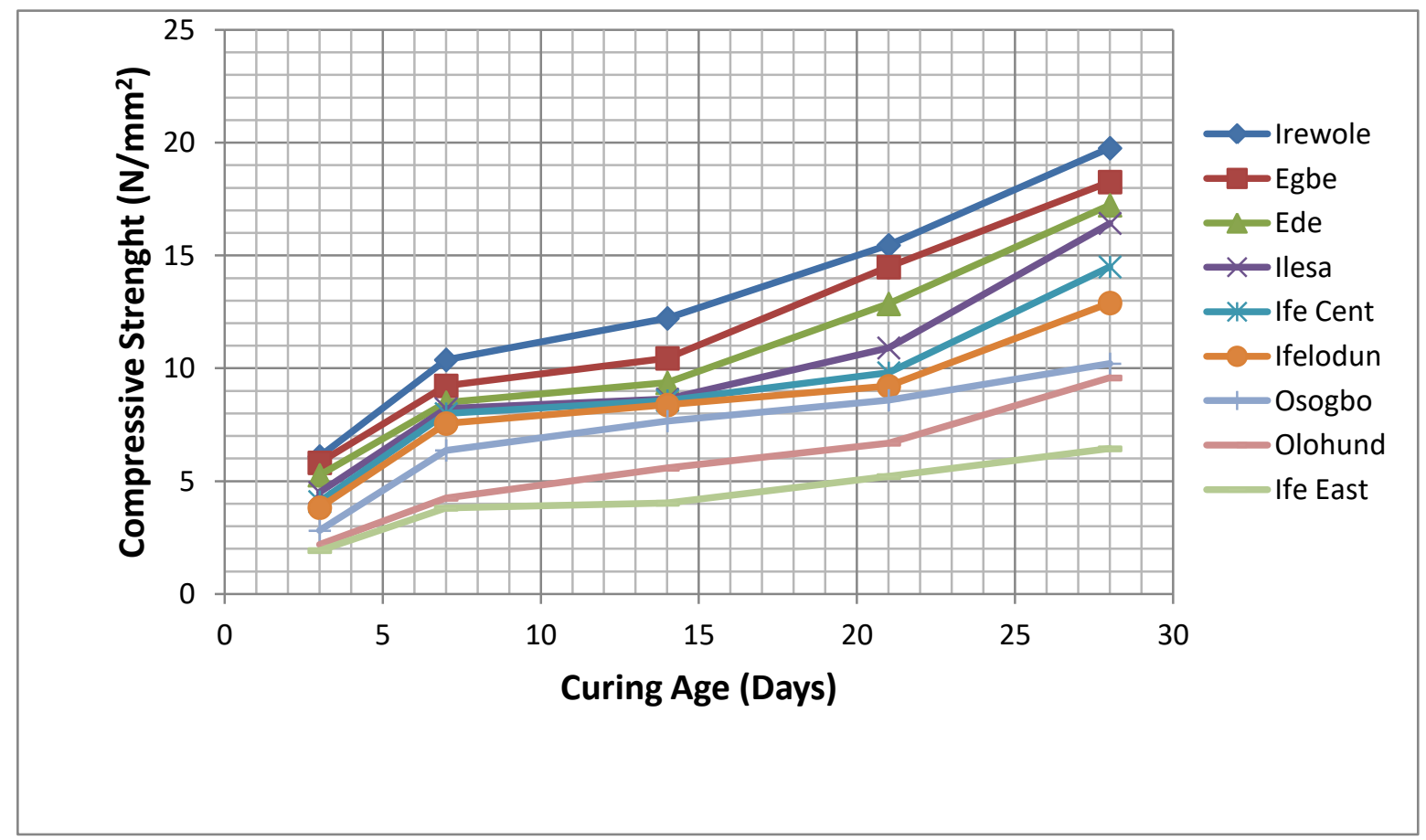

Figure 5 The summary of comprehensive strength $\mathrm{N} / \mathrm{mm}^{2}$ against the curing days of all the gravel samples in the Selected Local Governments 


\subsection{Aggregate Crushing Value Test (ACV)}

The Aggregate Crushing Value of the gravel samples collected from the selected Local Government was carried out and the test result shown in column chart in Figure 6 . The value of ACV for Irewole local Government is $19.13 \%$ which satisfy the minimum requirement for local gravel at the range $15-25 \%$, while that of Ife East Local Government is $44.86 \%$ indicating a lower gravel strength from the Local Government.

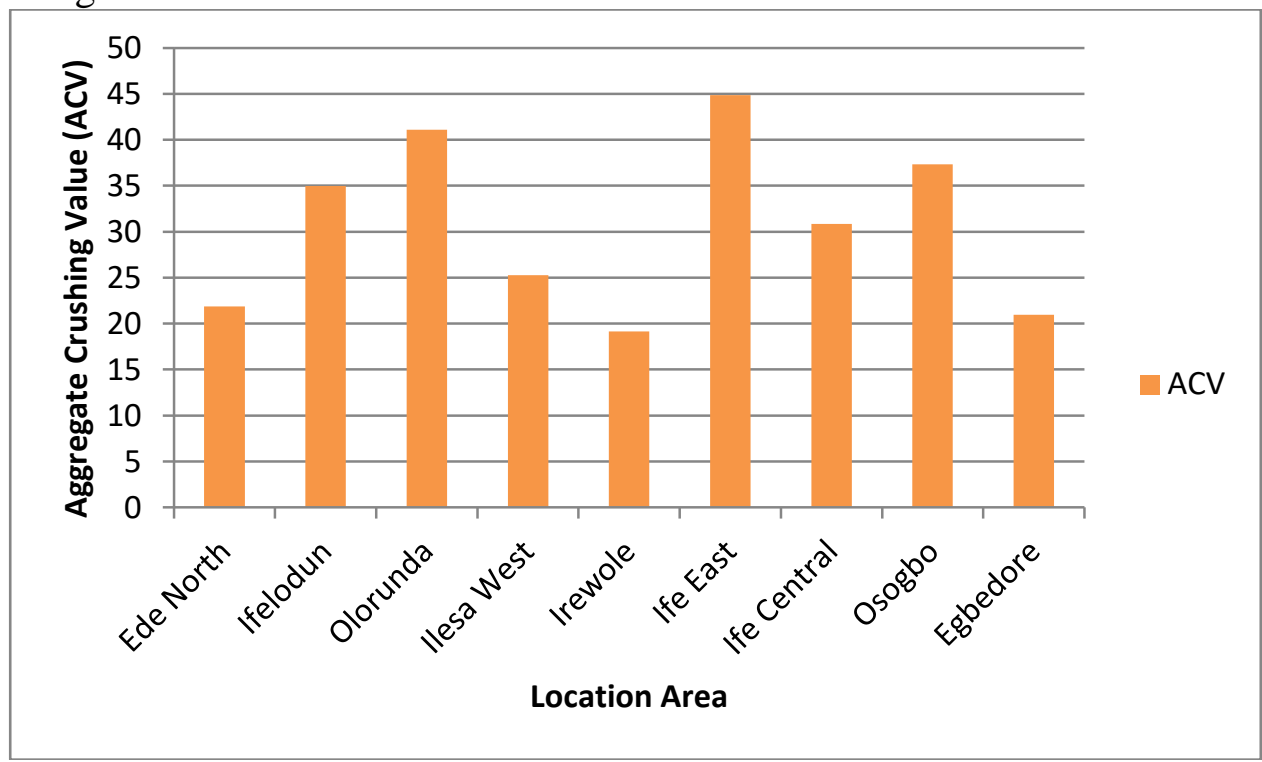

Figure6 Aggregate Crushing Value (ACV) of the gravel samples obtained from the selected local Government

\subsection{CONCLUSION}

Based on the results from the findings, the following conclusions were made:

(i) The gravel mining sites in Osun State include those located at Irewole Local Government Area, Egbedore Local Government Area, Ede North Local Government Area, Ilesa West Local Government Area, Ife Central Local Government Area, Ifelodun Local Government Area, Osogbo Local Government Area, Olorunda Local Government Area and Ife East Local Government Area were identified.

(ii) Gravel samples from Irewole Local Government, Egbedore Local Government, Ede North are well graded and falls within the envelope as required by AASHTO T27.

(iii) The samples from Irewole, Egbedore, and Ede Local Government have desirable compressive strength of $19.76 \mathrm{~N} / \mathrm{mm}^{2}, 18.26 \mathrm{~N} / \mathrm{mm}^{2}$ and $17.23 \mathrm{~N} / \mathrm{mm}^{2}$ at 28 days respectively, which were close to the minimum required strength of $20 \mathrm{~N} / \mathrm{mm}^{2}$ in accordance with BS812.

\subsection{REFERENCES}

I. Adeomi, A.S., Famakinwa, B.O. and Muhammed, W.A (2007). Desing of Concrete of Mixes Using Local Gravel Aggregate. Unpoblished B. Tech project, Department of Civil Engineering, LadokeAkintola University of Techology, Ogbomoso.

II. British Standard Institution ( 1990) : Methods of test for soils for civil engineering purposes. (:BS 1377) British Standard Institution 2 Park Street London W1A2BS.

III.Azer and Febel (1963). Geological Study of Western part of Nigeria. 
IV.British Standard institution (1970), Testing concrete: Specification for compression testing, BS (1881) part 115, London, British Standard Institution.

V. British Standard Institution (1983), Grading Requirement for aggregates, BS 882, London, British standard Institution.

VI. British Standard Institution (1983), Water absorption capacity testing, BS 1881: part 122, London, British Standard Institution.

VII. British Standard Institution (1990), Specific gravity determination test, BS 1377: test 6 (A), London, British Standard Institution.

VIII. British Standard Institution, (1990). Aggregate crushing value test, BS 812: part 110, London Standard Institution.

IX. British Standard Institution (1990), Moisture content determination, BS 812: part 109, London, British Standard Institution.

X. Oni A.A, (1984) "Rational Design of concrete Mixes Using Uncrushed Aggregate". A case study of share gravel deposit. Unpublished M. Eng. Thesis, Department of Civil Engineering, University of Ilorin.

XI. Shetty, M.S., Muenza, K. and Gall, N.D. (2005). "Quality Control of Concrete For Underground Section", the Indian concrete Journal, April, 2005, Volume 79, No 4, pages $11-21$.

XII. The Columbia electronic encyclopedia (2013). Characteristics of Aggregate. Retrieved from http://ww.cc.columbia.edu/cu/cup/ on 26th December, 2014. 